\title{
Penerapan model pembelajaran fun learning dalam meningkatkan hasil belajar menulis karangan narasi siswa sekolah dasar
}

Received:

$17 / 12 / 2021$

Accepted:

$19 / 12 / 2021$

Published:

$31 / 12 / 2022$

\author{
${ }^{1}$ Rezki Aulia Syukri, ${ }^{2}$ Aliem Bahri, ${ }^{3}$ Ummu Khaltsum \\ Universitas Muhammadiyah Makassar \\ 1ummukhaltsum@unismuh.ac.id
}

\begin{abstract}
The main problem in this study is whether the application of the fun learning model can improve the skills of writing narrative essays in the fifth-grade students of UPT SPF SD Inpres Parang Makassar City. This study aims to find out how the application of the fun learning model in improving narrative essay writing skills in class V UPT SPF SD Inpres Parang Makassar City. This type of research is class action research (Class Action Research) which consists of two cycles where each cycle is carried out four times. The focus of this research is 1) narrative essay writing skills and 2) the use of fun learning models in class V UPT SPF SD Inpres Parang Makassar City. The research procedure includes planning, implementing actions, observing, and reflecting. The research subjects were students of class $\mathrm{V}$, totaling 16 people. The data collected were analyzed using quantitative and qualitative analysis. The results of this study are: (1) In the first cycle, the average value of student learning outcomes for Class V UPT SPF SD Inpres Parang Makassar City is 58.7 (2) In the second cycle, the average value of student learning outcomes for class V UPT SPF is obtained. Inpres Parang Elementary School in Makassar City was higher at 82.5. The learning completeness of the fifth-grade students of UPT SPF SD Inpres Parang Makassar City has also increased. In the first cycle, from $3(18.7 \%)$ students achieved complete learning, while in the second cycle, $14(87.5 \%)$ students achieved learning mastery, and classical learning mastery was achieved. This means that learning completeness in cycle II is achieved classically because the number of students who complete is more than $85 \%$.
\end{abstract}

Keywords: Narrative writing skills, fun learning model, writing skills

\begin{abstract}
Abstrak
Masalah utama dalam penelitian ini adalah apakah penerapan model pembelajaran fun learning dapat meningkatkan keterampilan menulis karangan narasi pada murid kelas V UPT SPF SD Inpres Parang Kota Makassar. Penelitian ini bertujuan untuk mengetahui bagaimana penerapan model pembelajaran fun learning dalam meningkatkan keterampilan menulis karangan narasi pada murid kelas V UPT SPF SD Inpres Parang Kota Makassar. Jenis penelitian ini adalah penelitian tindakan kelas (Class Action Reaserch) yang terdiri dari dua siklus dimana setiap siklus dilaksanakan sebanyak empat kali pertemuan. Fokus penelitian ini adalah 1) Keterampilan menulis karangan narasi dan 2) Penggunaan model pembelajaran fun learning di kelas V UPT SPF SD Inpres Parang Kota Makassar. Prosedur penelitian meliputi perencanaan, pelaksanaan tindakan, observasi dan refleksi. Subjek penelitian adalah murid kelas $\mathrm{V}$ yang berjumlah 16 orang. Data yang terkumpul dianalisis dengan menggunakan analisis kuantitatif dan kualitatif.
\end{abstract}


Hasil penelitian ini yaitu: (1) Pada siklus pertama diperoleh nilai rata-rata hasil belajar murid Kelas V UPT SPF SD Inpres Parang Kota Makassar yaitu 58,7 (2) Pada siklus kedua diperoleh nilai rata-rata hasil belajar murid kelas V UPT SPF SD Inpres Parang Kota Makassar lebih tinggi yang mencapai 82,5. Ketuntasan belajar murid kelas V UPT SPF SD Inpres Parang Kota Makassar juga mengalami peningkatan. Pada siklus I, dari 3 (18,7\%) murid mencapai ketuntasan belajar, sedangkan pada siklus II sebanyak 14 (87,5\%) murid mencapai ketuntasan belajar dan ketuntasan belajar klasikal tercapai. Hal ini berarti ketuntasan belajar pada siklus II tercapai secara klasikal karena jumlah murid yang tuntas lebih dari $85 \%$.

Kata kunci: Keterampilan menulis karangan narasi, model pembelajaran fun learning, keterampilan menulis.

\section{Pendahuluan}

Keterampilan berbahasa ada empat aspek, yaitu menyimak, membaca, berbicara, dan menulis. Dari keempat aspek tersebut dapat dibagi menjadi dua kegiatan yaitu kegiatan produktif dan reseptif. Menyimak dan membaca merupakan kegiatan yang reseptif yaitu kegiatan yang dilakukan seseorang dalam menerima pesan dari pembicara atau penulis, sedangkan dua aspek lain berbicara dan menulis merupakan kegiatan yang produktif. Yunus berpendapat bahwa aktif reseptif (menerima pesan) menyimak dan membaca, sedangkan aktif produktif (menyampaikan pesan) berbicara dan menulis (Yunus, 2013).

Keterampilan menulis dapat menjadi penilaian untuk mengukur penguasaan berbahasa yang lain. Alasannya, kemampuan menyimak murid dapat diukur dengan mengungkapkan kembali objek atau sesuatu yang disimak secara tertulis (Arif \& Iskandar, 2018). Pemahaman terhadap bacaan dapat diuji melalui tes tertulis, sebuah pembicaraan akan lebih terarah bila didahului oleh konsep tertulis.

Dunia pendidikan formal, keterampilan menulis sangat berperan terutama dalam menyusun karangan. Namun kenyataannya masih banyak kesulitan yang dihadapi oleh murid dalam menulis sebuah karangan dalam hal inilah yang terjadi di kelas V UPT SPF SD Inpres Parang Kota Makassar. Masih banyak murid yang belum mampu membuat karangan sendiri. Murid kesulitan dalam menuliskan pengalamannya tentang sebuah objek yang berhubungan dengan apa yang dialaminya dalam bentuk karangan. Terlebih lagi guru masih belum memahami betul solusi yang diberikan atas kekurangan muridnya, dan untuk mengurangi kendala tersebut, murid harus dibina, dibekali dalam meningkatkan kemampuan menulis. Pada pembelajaran sastra di sekolah dasar, membutuhkan kemampuan khusus murid dalam melahirkan atau menciptakan sebuah hasil karya yang baik berupa karangan dan cerita pendek (Irma et al., 2020; Siwi, 2017). Dalam membuat karangan, murid membutuhkan sebuah model pembelajaran khusus dalam pembelajarannya.

Latihan mengarang merupakan salah satu cara yang dapat digunakan untuk mengasah kemampuan murid dalam mengembangkan ide, pikiran, perasaan dalam bentuk karangan. Sebab jika seseorang memiliki bakat, bila bakat itu tidak disertai dengan latihan menulis, maka tidak akan berkembang. Dengan kata lain, bakat disertai dengan latihan dan praktek sehingga dapat menjadi seorang penulis yang baik. Di

\section{JUDIKDAS: Jurnal Ilmu Pendidikan Dasar Indonesia Volume 1 - No. 1}


samping menulis, bakat seseorang hendaknya dipupuk sejak dini sehingga proses latihan dan praktek yang berkesinambungan dapat meningkatkan kemampuan dan keterampilan menulis seseorang (Wiratman et al., 2018).

Pada pembelajaran mengarang di sekolah dasar, biasanya guru menentukan topik yang akan dikarang. Murid membuat karangan sesuai dengan topik yang ditentukan oleh guru, pada prakteknya tidak semua murid dapat mengarang jika belum melihat objek yang akan dijadikan topik. Atas dasar inilah penulis bermaksud meneliti apakah karangan bebas dapat meningkatkan kemampuan murid menulis karangan dengan menggunakan model pembelajaran fun learning.

Berdasarkan hasil observasi awal peneliti pada tanggal 3 Mei 2021 di kelas V UPT SPF SD Inpres Parang Kota Makassar menemukan fakta bahwa masih menggunakan metode yang konvensional. Peran guru belum optimal dalam pembelajaran menulis karangan narasi. Dalam membelajarkan menulis karangan narasi, guru langsung memberikan judul kemudian murid diminta membuat karangan dari judul tersebut. Guru kurang memberikan contoh-contoh teknik menulis yang baik dan tidak membimbing murid ketika membuat karangan. Tak jarang pula ketika murid mengerjakan tugas, guru malah sibuk mengerjakan administrasi atau megoreksi hasil ulangan murid. Guru juga kurang merangsang kemampuan berfikir muridnya, sehingga daya kreatifitas murid kurang berkembang. Di samping itu, guru belum memanfaatkan media atau alat peraga dalam pembelajaran menulis karangan narasi di kelas. Hal tersebut menyebabkan murid kurang tertarik dalam pembelajaran dan motivasi untuk menulis rendah. Mereka terlihat jenuh dan kurang bersemangat jika diberi tugas oleh guru untuk menulis karangan narasi.

Dari hasil pengamatan dalam pembelajaran menulis karangan narasi, ditemukan pula masalah yang dihadapi murid kelas V UPT SPF SD Inpres Parang Kota Makassar dimana murid mengalami kesulitan jika diberi tugas untuk menulis karangan narasi oleh guru. Kesulitan yang dihadapi para peserta didik diantaranya mengenai ejaan, penggunaan tanda baca, pemilihan kosakata, penyusunan kalimat hingga kesulitan mengembangkan ide cerita ke dalam bahasa tulis. Pada umumnya kalimat yang dibuat peserta didik juga memuat kata yang diulang-ulang sehingga menjadi kalimat yang tidak efektif. Akibatnya, karangan narasi yang dihasilkan kurang memberikan gambaran yang jelas tentang rangkaian peristiwa atau kejadian, hasil belajar untuk keterampilan menulis karangan narasi pada kurikulum 2013 di semester genap tahun ajaran 2020/2021 murid kelas V di UPT SPF SD Inpres Parang Kota Makassar menunjukkan dari 16 murid hanya sekitar 6 orang yang mampu membuat karangan narasi, dan 10 orang yang belum mampu membuat karangan narasi, ini terlihat kurang menggembirakan dan sangat membutuhkan sebuah metode. Dalam pembelajaran bahasa Indonesia khususnya pada materi menulis karangan juga masih sangat rendah, murid yang mencapai nilai KKM hanya 6 orang atau sekitar 37,5\% dan yang belum mampu mencapai nilai KKM ada 10 orang atau sekitar 62,5\% dari standar KKM yang telah ditentukan sekolah, yaitu 70. Oleh karena itu, penelitian tentang pembelajaran menulis karangan dengan menggunakan model pembelajaran fun learning perlu 


\section{4 | Rezki Aulia Syukri, Aliem Bahri, dan Ummu Khaltsum}

dilakukan sebagai upaya meningkatkan pembelajaran menulis karangan di sekolah tersebut.

Model pembelajaran yang digunakan adalah model pembelajaran fun learning, model pembelajaran tersebut berusaha menciptakan suasana yang fun (menyenangkan). Melalui penciptaan suasana yang fun, maka murid akan memperoleh suasana yang menyenangkan hatinya. Hal tersebut memengaruhi kondisi otak murid untuk menyerap informasi yang disampaikan secara maksimal. Hernowo (2012) mengungkapkan bahwa dalam pembelajaran menulis, seseorang harus berada dalam keadaan fun karena fun inilah yang menentukan berlangsung tidaknya seseorang menulis.

Menciptakan suasana yang fun dalam pembelajaran menulis dapat dilakukan dengan mendayagunakan kerja kedua otak murid. Menulis membutuhkan daya imajinasi yang kuat diimbangi dengan penggunaan kosakata untuk mengungkapkan imajinasi yang ada ke dalam bentuk cerita. Daya imajinasi tersebut berhubungan dengan kerja kedua otak kita yaitu otak kanan dan otak kiri. Otak kiri berfungsi dalam hal perbedaan, angka, urutan, tulisan. Otak kanan berfungsi dalam hal persamaan, khayalan, kreativitas, emosi, ruang, dan makna dalam menciptakan sebuah karangan dalam pembelajaran menulis karangan narasi. Untuk itu, model pembelajaran fun learning dalam pembelajaran ini diharapkan dapat menjadi salah satu alternatif pemecahan masalah kesulitan belajar, khususnya dalam pembelajaran menulis karangan narasi. Model pembelajaran ini dirancang untuk mendobrak situasi yang membosankan dalam pembelajaran di sekolah (Bobbi De Porter, 2015). Berdasarkan uraian tersebut maka peneliti tertarik melakukan penelitian tentang penerapan model pembelajaran fun learning dalam meningkatkan hasil belajar menulis karangan narasi pada murid sekolah dasar.

\section{Metode Penelitian}

Penelitian ini tergolong penelitian tindakan yang berbasis kelas (classroom action research) hal ini sesuai dengan Sanjaya (2013) yang menyatakan bahwa PTK diartikan sebagai pengkajian masalah pembelajaran di dalam kelas melalui refleksi diri dalam upaya untuk memecahkan masalah tersebut dengan cara melakukan berbagai tindakan yang terencana dalam situasi nyata serta menganalisis setiap pengaruh dari perlakuan tersebut. Penelitian ini dilaksanakan di kelas V UPT SPF SD Inpres Parang Kota Makassar. Subjek penelitian adalah murid kelas V UPT SPF SD Inpres Parang Kota Makassar direncanakan pada tahun ajaran 2021/2022 sebanyak 16 orang murid, dengan rincian 10 orang laki-laki dan 6 orang perempuan.

Faktor yang diselidiki: 1) Faktor Proses: Dengan melihat hal-hal yang terjadi selama berlangsungnya pembelajaran dengan model pembelajaran fun learning. 2) Faktor Hasil: Dengan melihat kemampuan menulis karangan narasi murid setelah tes akhir yang diberikan setiap siklus. Penelitian ini direncanakan dalam dua siklus, tiap siklus dirancang tiga kali pertemuan, pertemuan satu dan kedua untuk melangsungkan proses dan pertemuan ketiga evaluasi pembelajaran. 
Instrumen penelitian adalah lembar observasi, tes hasil belajar dan dokumentasi. Teknik pengumpulan data dalam penelitian ini adalah tes, lembar observasi. Data yang diperoleh kemudian dianalisis dengan menggunakan analisis deskriptif kuantitatif dan kualitatif.

\section{Hasil}

Gambaran mengenai aktivitas belajar murid pada siklus I, dimana dari 16 murid kelas V UPT SPF SD Inpres Parang Kota Makassar yang di observasi terkait aspek-aspek aktivitas belajar, hasilnya dapat dijelaskan dalam skala deskriptif sebagai berikut; Murid yang hadir pada saat proses pembelajaran sebesar 93,7\%; Murid yang memperhatikan penjelasan guru sebesar 48,1\%; Murid yang menjawab pertanyaan guru sebesar $45,6 \%$; Murid yang mengerjakan karangan narasi sebesar 51,9\%; Murid yang mengajukan pertanyaan kepada guru dan murid lain sebesar 31,3\%; Murid yang berpartisipasi dalam kegiatan bermain sambil bernyanyi sebesar 51,9\%; dan Murid yang melakukan kegiatan lain pada saat proses pembelajaran berlangsung (ribut, bermain, mengganggu teman, keluar masuk kelas) sebesar 45,6\%.

Seperti yang diungkapkan oleh Siti Masrohah (2012) dengan hasil penelitian yang diperoleh yaitu: Model Fun Learning dapat meningkatkan kemampuan menulis karangan narasi, hal ini dapat dilihat pada awal pembelajaran nilai rata-rata yang diperoleh murid $57,50 \%$ kemudian mengalami peningkatan $24,82 \%$ menjadi 82,32 dari 40 murid. Hasil penelitian Siwi menunjukkan bahwa metode fun learning dapat meningkatkan kemampuan murid dalam menulis karangan narasi (Siwi, 2017), hal ini dapat dilihat dari rata-rata hasil belajar murid pada siklus I dan siklus II yang mengalami peningkatan rata-rata nilai hasil belajar murid adalah 53 pada siklus I, sedangkan pada rata-rata nilai hasil belajar adalah 73 pada siklus II . Selain itu ketuntasan belajar pada siklus I untuk kualifikasi cukup adalah $62 \%$ dan kualifikasi baik adalah $42 \%$ dan mengalami peningkatan pada siklus II untuk kualifikasi kurang adalah 0, kualifikasi cukup adalah 14\%, kualifikasi baik adalah 86\%. Muharam Saribi (2014) dengan hasil penelitian yaitu: dengan menggunakan metode fun learning dapat meningkatkan kemampuan menulis karangan narasi, hal ini dapat dilihat dari hasil tes menulis karangan narasi siklus I 68,05 dengan ketuntasan belajar klasikal 31,57\%, meningkat siklus II 80,27 dengan ketuntasan belajar klasikal 77,27\% dari 38 murid.

Masih ada beberapa murid yang sibuk dengan aktivitasnya sendiri saat guru menjelaskan materi. Hal tersebut mengakibatkan guru sering menegur murid di sela-sela memberi penjelasan. Bahkan ketika guru menegur murid yang sedang gaduh, itupun hanya akan menenangkan murid dalam beberapa saat. Ketika guru kembali menjelaskan materi, tidak sedikit murid yang kembali membuat gaduh.

Murid melakukan koreksi terhadap tulisan temannya masih ada beberapa murid yang kurang serius. Mereka justru bermain-main sendiri dengan teman semejanya atau bahkan hanya bertopang dagu dan tidur-tiduran dengan meletakkan kepalanya di atas meja. Melihat keadaan tersebut pun guru tidak mampu berbuat banyak selain menegurnya. 


\section{6 | Rezki Aulia Syukri, Aliem Bahri, dan Ummu Khaltsum}

Berkaitan dengan peserta didik, murid sudah cukup mampu dalam mengidentifikasi letak kesalahan yang terdapat dalam karangan temannya, hal ini terlihat dari hasil koreksian murid yang sudah maksimal dikoreksi. Karangan yang berhasil dikoreksi dengan maksimal oleh murid dapat diketahui dengan banyaknya coretan pembetulan di dalamnya, baik dari aspek isi maupun ejaannya. Hanya saja dari koreksian tersebut, beberapa murid masih belum mampu membetulkannya. Sehingga secara singkat dapat dinyatakan bahwa murid sudah mampu mengoreksi kesalahan temannya, akan tetapi belum maksimal dalam membetulkan kesalahan tersebut. Mereka tahu jika karangan temannya ada beberapa kesalahan, hanya saja masih ragu dan takut untuk membetulkannya. Sehingga masih banyak coretan koreksi yang tanpa tulisan pembetulan.

Gambaran aktivitas belajar murid pada siklus II, dimana dari 16 murid kelas V UPT SPF SD Inpres Parang Kota Makassar yang di observasi terkait aspek-aspek aktivitas belajar, hasilnya dapat dijelaskan dalam skala deskriptif sebagai berikut; Murid yang hadir pada saat proses pembelajaran sebesar 98,1\%; Murid yang memperhatikan penjelasan guru sebesar 79,4\%; Murid yang menjawab pertanyaan guru sebesar $75 \%$; Murid yang mengerjakan karangan narasi sebesar 76,9\%; Murid yang mengajukan pertanyaan kepada guru dan murid lain sebesar 54,4\%; Murid yang berpartisipasi dalam kegiatan bermain sambil bernyanyi sebesar 79,4\%; dan Murid yang melakukan kegiatan lain pada saat proses pembelajaran berlangsung (ribut, bermain, mengganggu teman, keluar masuk kelas) sebesar 18,7\%.

Pelaksanaan tindakan pada siklus II pada dasarnya sama pada siklus I, akan tetapi kualitas pembelajaran menulis karangan narasi pada siklus II mengalami peningkatan, hal ini terlihat dari tercapainya sejumlah indikator yang telah ditetapkan. ketercapaian indikator tersebut meliputi meningkatnya keaktifan, perhatian dan konsentrasi, serta minat dan motivasi murid dalam proses pembelajaran. Disamping itu, kekurangan-kekurangan yang ditemui dalam siklus I dapat diatasi dengan baik oleh guru pada siklus II. Pada siklus II murid lebih aktif selama proses pembelajaran, murid lebih memperhatikan penjelasan guru dan memiliki motivasi yang tinggi dalam pembelajaran. Keaktifan, perhatian, dan motivasi murid meningkat karena guru menyampaikan penjelasan materi dengan lebih menarik, misalnya diselingi humor serta sesekali memanggil nama-nama murid. Dengan kegiatan tersebut, murid akan merasa lebih diperhatikan sehingga mereka tidak canggung untuk aktif saat menjawab pertanyaan guru atau mengutarakan pendapatnya saat proses pembelajaran.

\section{Diskusi}

Pada pelaksanaan siklus I, aktivitas murid yang diperoleh belum sesuai tujuan yang ingin dicapai. Rendahnya aktifitas murid dapat dilihat dari hasil evaluasi dimana hanya terdapat 3 murid dari 16 murid secara keseluruhan yang berhasil mencapai standar KKM yang sudah di tentukan terhadap penguasaan materi pelajaran. Berdasarkan data yang diperoleh dari tes siklus I dapat dilihat bahwa kemampuan 
menulis karangan narasi murid kelas V UPT SPF SD Inpres Parang Kota Makassar belum sesuai kriteria yang ditentukan, yaitu rata-rata yang harus diperoleh murid di kelas adalah $85 \%$ dari jumlah murid yang mendapatkan nilai sesuai standar KKM 70. Data hasil penelitian pada siklus I di atas dianggap belum meningkat, karena rata-rata yang dicapai hanya 18,7\% dari 16 murid. Walaupun pada siklus I belum terjadi peningkatan kemampuan menulis karangan narasi,belum mencapai indikator yang telah ditetapkan. Jadi dapat disimpulkan bahwa siklus I belum berhasil dan perlu dilanjutkan ke siklus II.

Pada pelaksanaan siklus II, aktifitas murid lebih dioptimalkan. Sesuai dengan hasil tes yang telah dilakukan pada siklus II hasil yang diperoleh adalah 14 murid atau $87,5 \%$. Hasil belajar murid mengalami peningkatan dari 3 murid atau 18,7\% menjadi 87,5\% atau 14 murid yang berhasil mencapai nilai stándar KKM. untuk menguasai materi pelajaran. Peneliti menunjukkan bahwa pembelajaran dengan menggunakan model pembelajaran fun learning dalam peningkatkan kemampuan menulis karangan narasi murid kelas V UPT SPF SD Inpres Parang Kota Makassar sudah mendapat hasil yang maksimal karena indikator keberhasilan telah tercapai dengan baik atau mengalami peningkatan dengan nilai rata-rata 82,5 dari 16 murid.

Berdasarkan analisis deskriptif aktivitas penulisan karangan murid Kelas V UPT SPF SD Inpres Parang Kota Makassar. Jika dibandingkan hasil observasi siklus I dan siklus II, persentase rata-rata jumlah murid yang pengungkapan karangannya jelas meningkat dari $62,5 \%$ menjadi $90,6 \%$. persentase rata-rata jumlah murid yang bagus penciptaan kesatuan dan pengorganisasian meningkat dari $65,6 \%$ menjadi $90,6 \%$. persentase rata-rata jumlah murid yang karangannya efektif dan efisien meningkat dari $75 \%$ menjadi $90,6 \%$. persentase rata-rata jumlah murid yang tepat penggunaan bahasanya meningkat dari $65,6 \%$ menjadi $91,8 \%$. persentase rata-rata jumlah murid yang karangannya ada variasi kalimatnya meningkat dari 65,6\% menjadi $91,8 \%$. persentase rata-rata jumlah murid yang karangannya cermat meningkat dari $75 \%$ menjadi $91,8 \%$. persentase rata-rata jumlah murid yang karangannya objektif meningkat dari $75 \%$ menjadi $91,8 \%$.

Berdasarkan hasil observasi perencanaan, pelaksanaan, evaluasi serta refleksi, maka disimpulkan bahwa penelitian ini telah berhasil yaitu dengan tercapainya indikator pada judul penelitian ini: peningkatan keterampilan menulis Karangan narasi melalui model pembelajaran fun learning murid kelas V UPT SPF SD Inpres Parang Kota Makassar.

\section{Kesimpulan}

Berdasarkan hasil penelitian dan pembahasan, maka dapat disimpulkan bahwa hasil menulis karangan narasi pada murid kelas V UPT SPF SD Inpres Parang Kota Makassar mengalami peningkatan melalui model pembelajaran fun learning. Adapun hasil penelitian yang dilakukan selama dua siklus dapat diidentifikasi bahwa hasil belajar murid kelas V UPT SPF SD Inpres Parang Kota Makassar melalui model 
pembelajaran fun learning mengalami peningkatan dapat dilihat pada hasil belajar murid yaitu perolehan rata-rata skor hasil belajar murid pada siklus I 58,7. Pada siklus II, rata-rata skor hasil belajar murid mengalami peningkatan menjadi 82,5 berada pada kategori tinggi dari skor ideal 100. Ketuntasan belajar menulis karangan murid kelas V UPT SPF SD Inpres Parang Kota Makassar juga mengalami peningkatan. Pada siklus I, dari $3(18,7 \%)$ murid mencapai ketuntasan belajar, sedangkan pada siklus II sebanyak $14(87,5 \%)$ murid mencapai ketuntasan belajar dan ketuntasan belajar klasikal tercapai. Terjadi peningkatan aktivitas belajar murid melalui model pembelajaran fun learning yang ditandai dengan meningkatnya keaktifan belajar murid dalam proses pembelajaran sesuai dengan hasil observasi selama proses tindakan kelas berlangsung.

Berdasarkan hasil penelitian ini, maka saran yang perlu disampaikan adalah sebagai berikut: (1) Ada baiknya para pembina pendidikan memberikan sosialisasi tentang penerapan model pembelajaran fun learning kepada para guru sekolah dasar. (2) Pihak guru disarankan untuk menerapkan pembelajaran menulis dengan model pembelajaran fun learning. (3) Pihak peneliti lain disarankan untuk mengembangkan penelitian ini dengan menerapkan pembelajaran bahasa Indonesia melalui model pembelajaran fun learning pada aspek lainnya dalam pembelajaran bahasa Indonesia

\section{Referensi}

Arif, T. A., \& Iskandar, I. (2018). TEKNIK PENYUSUNAN BAHAN AJAR BAHASA INDONESIA BAGI GURU DI SEKOLAH DASAR. Prosiding Seminar Nasional Pendidikan, 1(1). https://jurnal.umj.ac.id/index.php/SNP/article/view/2802

Bobbi De Porter, Mark Reardon. 2015. Membiasakan Belajar Nyaman dan Menyenangkan. Bandung: Penerbit Kaifa.

Hernowo. 2012. Mengikat Makna. Bandung: KAIFA.

Irma, A., Syamsuri, A. S., \& Arief, T. A. (2020). Keefektifan Teknik Mind Mapping Berbantukan Media Gambar Terhadap Pembelajaran Menulis Paragraf Deskripsi Siswa Kelas IV Sekolah Dasar Kabupaten Pangkep. Jurnal Profesi Keguruan, 6(1), 54-63. https:// doi.org/10.15294/JPK.V6I1.23216

Masrohah, Siti. 2012. Peningkatan Kemampuan Menulis Karangan narasi Dengan Model pembelajaran Fun Learning Murid Kelas VIII Madrasah Tsanauwiyah (MTS) Mathla'ul Anwar Kota Malang. Skripsi Universitas Negeri Malang.

Muharam, Saribi. 2014. Peningkatan Kemampuan Menulis Karangan Narasi dengan Penerapan Model pembelajaran Fun Learning Pada Murid Kelas V SDN 55 Kota Bengkulu. Skripsi Universitas Negeri Bengkulu.

Sanjaya, Wina. 2013. Penelitian Tindakan Kelas. Jakarta: Kencana.

Siwi, D. (2017). Peningkatan keterampilan menulis karangan narasi melalui model Directed Writing Activity (DWA) pada siswa kelas IV SDN Bareng 2 Kota Malang / Dwiretnaning Siwi. Universitas Negeri Malang.

Yunus, Surya. 2013. Kapita Selekta Kependidikan SD. Jakarta: Universitas Terbuka.

Wiratman, A., Yuliana, I., \& MW, R. (2018). LEARNING OF VOCATIONAL SKILL FOR EMPOWERMENT THE SPIRIT OF SPECIAL NEEDS OF CHILDREN. JPI (Jurnal 
Penerapan model pembelajaran fun learning ... |59

Pendidikan Inklusi), 2(1), 21-29. https:// doi.org/10.26740/INKLUSI.V2N1.P21-29 
60 | Rezki Aulia Syukri, Aliem Bahri, dan Ummu Khaltsum

--- Halaman ini sengaja di kosongkan ---

JUDIKDAS: Jurnal Ilmu Pendidikan Dasar Indonesia Volume 1 - No. 1 